\title{
巨大自然災害発生後の生存·生活環境変化 に基づく地域のレジリェンス性評価
}

\author{
猪原 暁 1 ・渡邊 啓太 $2 \cdot$ 杉本 賢二 $3 \cdot$ 加藤 博和 4 ・林 良嗣 5 \\ 1学生会員 名古屋大学 大学院環境学研究科（广464-8603 名古屋市千種区不老町） \\ E-mail: sinohara@urban.env.nagoya-u.ac.jp \\ 2非会員 名古屋鉄道株式会社（一450-8501 名古屋市中村区1丁目2番4号）

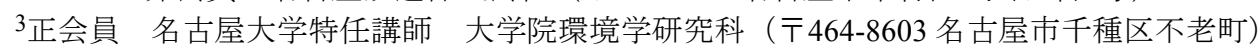 \\ 4正会員 名古屋大学准教授 大学院環境学研究科（同上） \\ 5フェロー 中部大学教授 総合工学研究所（广487-0027 愛知県春日井市松本町1200番地)
}

\begin{abstract}
巨大自然災害に対する防災・減災施策を講じる上で，地域のレジリエンス性（抵抗力，回復力）に関す る情報を整備することが重要である。本研究では, 災害によって死亡・負傷していない住民を対象に, 発 災以降の生存・生活環境変化の動向を踏まえ, 被災者のQOL（生活の質：Quality of Life）の低下量を用い て, 地域のレジリエンス性を定量評価する手法を構築した. 想定されている南海トラフ地震に適用した結 果, 内陸部ではQOLは早期に回復するが，甚大な津波被害を被る沿岸部ではQOLの回復は遅くなることが 明らかとなった。また，東日本大震災で行われた「くしの歯作戦」の方針を基に想定した道路復旧シナリ オにより，広域幹線道路周辺地域から支援が進み，QOL回復に重要な役割を果たすことを示した。
\end{abstract}

Key Words : quality of life, emergency management, resilience, Nankai Trough Earthquake

\section{1. はじめに}

日本では，東日本大震災や豪雨等気象災害などの大規 模な自然災害の頻発によって，防㷋・減災への意識が急 激に高まっている，東日本大震災では，従来の想定を大 幅に上回る巨大な地震と津波により, 東北地方と関東地 方の太平洋沿岸部に壞滅的な被害がもたらされた。 こう した自然災害は, 大量の死傷者をもたらすだけでなく, 生き残って怪我がない人たちも, 日常より劣悪な生存・ 生活環境の中で一定期間暮らすことを余儀なくされる. これは, 家屋や, 道路・電力網・通信網・災害拠点施設 等のインフラ, そして病院やスーパーマーケットといっ た様々な施設が破壊され使用不能となり，さらに日常生 活を支える様々なサービスも機能しなくなることが原因 である．これによって食料等の基本的な物資や場所が不 足したり, 救助・避難・復旧等の活動に支障が生じたり 寸る. 劣悪な環境に長期間置かれた場合, 健康を損なう ことや，場合によっては死に至ることもある．例えば, 東日本大震災では地震や津波などによる死者・行方不明 者は約 18,000 人であるが，被災後の関連死者数は約 3,400 人にも上る1．

こうした「大規模災害の発生，甚大な被害，長期間に
渡る復旧・復興」という繰り返しを避けるために, 内閣 府は, 人命を守り抜き, 行政・経済社会を維持し, 財産 施設等に対する被害を軽減し，迅速な復旧・復興を可能 にすることを基本方針とする国土強勒化（レジリエン ス）の推進を掲げている2)。これは国や地域の経済社会 に関わる幅広い対象に対して, 経済社会のシステム全体 の抵抗力，回復力を確保することを目的としている.

大規模災害に対する防災・減災施策を検討寸るに当た り，地域のレジリエンス性に関する情報整備は非常に重 要である. 発災直後は状況が時々刻々と変化するのに対 し，情報が乏しく混乱する，その中で，限られた資源 （インフラ復旧への人員投入や生活サービス供給）を適 時適切な場所に供給していくことが求められる. そのた めには，周辺状況によって変化していく被災者の生存・ 生活環境を時系列で把握できる体制を整えておく必要が ある。これは特に, 発災直後における被災者の生活水準 の低下抑制と, 避難から復旧, 復興に至るまでのより早 い回復のために，事前対応策をハード・ソフトの両面か ら検討しておくことに資する。

本研究では，巨大自然災害発生後の被災者の生存・生 活環境の時系列変化を「生活の質(Quality of Life : QOL)」 指標で表し，その低下量で地域のレジリエンス性を評価 
する手法を構築する. これを用いて, 将来の巨大自然災 害発生に対する，地域のレジリエンス性を把握すること を目的とする.

\section{2. 既往研究と本研究の位置づけ}

\section{(1) 災害影響評価の概観}

災害がもたらす被害は，単純に言えば，人や建物・イ ンフラなどの資産ストックに対する直接被害，それに伴 う社会・生産・生活基盤の機能として, 財・サービスの 生産フローへの影響に伴い, 被災した地域ひいては被災 国全体の経済損失として現れる，直接被害の大半は，発 災の瞬間から数時間の間に発生する。これに対し，間接 被害は社会・経済インフラが被った直接被害に起因する 二次的なものであり，災害後の様々な時期において顕在 化し，その被害は発災前のレベルに戻るまで長期間に渡 り発生，継続する.

このような被害を評価する手法として，内閣府経済社

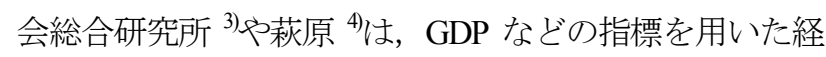
済損失の評価や，死傷者数，建物倒壊数などの物理的な 指標を用いている.これらは基本的に過去の災害を参考 に被害の様相とその原因を被害関数として定義し用いて いる。こうした評価は被害量の低減には有用であるが, 長期に渡る被災者の生活まで考慮した評価はできない。

近年では，頻発する自然災害を受け，津波や土砂災害 などを想定したハザードマップの普及が進展し, 避難所 や避難経路などの情報提供も行われている5 のが，これ らは災害発生直後の被害低減策であり, 避難から復旧, 復興に至るまでのより長期的な視点にたった対策ではな い.

したがって，長期間に渡る被災者の生活環境覀化を考 慮するためにそれを把握しておくことによる事前対応策 の検討が必要である.

\section{（2）被災者の生活環境}

被災者の生活環境やインフラの被害に着目した研究と して, 近藤らわによる道路閉塞を考慮した孤立日数を評 価した研究や，太田ら ${ }^{8}$ によよる食料備蓄量から孤立集落 の自立性を評価した研究がある。しかし，これらでは被 災者の時々刻々と変化するニーズが考慮されておらず, 他インフラとの対策の優先順位づけの比較に適さない.

次に, 被災者の心理変化に着目した研究として, 城 ${ }^{9}$ のような面談による調査や松井 ${ }^{10)}$ のようなアンケート調 査によるものがあり，ニーズ変化に合わせた柔軟な支援 活動の必要性を主張している。しかし，実際の災害時に 脆弱な地区を明確化し，対応策を提示寸るまでに至って いない.
生活者の視点から災害の影響を検討寸る際には，生 存・生活環境変化と心理変化の両方の要因を考慮する必 要がある. 紙野 ${ }^{11)}$ や塚本・波床 ${ }^{12}$ は, 被苂者のニーズ変 化とインフラ復旧状況との関係を時系列で整理している が，定性的評価に留まっている．定量評価を試みた研究 として, 能島ら ${ }^{13)}$ や塩野ら ${ }^{14}$ はライフラインの機能状況 と被災者ニーズ変化を考慮して被災者の生活環境とイン フラの被害を評価している. 高野ら ${ }^{15)}$ は各種インフラの 復旧状況との相互関係も含めた総合的な評価手法として, 居住地における生活の質（QOL）を指標化し，災害時の 被災者の生活水準の変化や, 生活水準確保にインフラ被 害が及ぼす影響メカニズムの整理，そして確保のために 必要な外部からの代替物投入などを総合的に考慮した QOL 評価手法を構築している.この手法により, 災害 時における生活水準の時系列評価が可能であるが，適用 にわたっては被災後の実際に観測されたデータが必要に なる．また，今後起こりうる自然災害の予測評価を可能 にするまで整理がなされていない.

本研究では, 被災者の生存・生活環境をQOL值で定量 評価し, 被災後の大きな低下からその後の回復過程まで を時系列で評価する. 図-1に大規模災害発生後のQOL水 準変化とレジリエンス性に関する概略図を示す。レジリ エンス性はこのQOL水準の平常時からの低下量の時間積 分值として捉え, この積分值が小さければ，災害に対す るレジリエンス性が高い地域といえる，図-1のうち，直 接被害による死亡および負傷と, 生存・生活環境を対象 に評価を行う。特に, 生存・生活環境の部分のQOL評価 を詳細に検討する.

なお，本研究では扱わないが，インフラや医療施設の 機能や稼働の是非や発災後の被災者の生命・健康（二次 死亡含む）を影響を評価する研究として，杉本ら ${ }^{19}$ は大 規模自然災害による被災者の生命及び健康へのダメージ を時系列で予測し，余命指標DALY（障害調整年数）を 用いて定量評価する手法を提案している. DALYは罹患 や傷害に起因する障害の程度を重みとしてどれだけ健康 な 1 年が失われたかという尺度で算定するものである. 一方, 本研究で扱うQOL指標によって, 被災者の主観的 なニーズから生存・生活環境を評価することができ，先

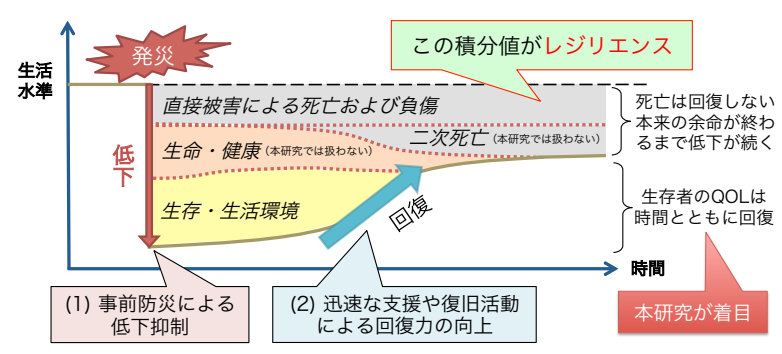

図-1 大規模苂害発生後のQOL水準の変化とレジリエンス 
述のDALY評価と併せて被災者の生活水準を総合的に評 価することが可能となる.

\section{3. 巨大自然災害による生存 ·生活環境変化の評 価システム}

\section{（1）システムの基本的な考え方}

災害がもたらす被害は，単純に言えば，人や建物・イ ンフラな都市環境のQOL評価の考え方として, Myers ${ }^{17}$ は環境の物理量と個人の主観的評価值の両面から計測さ れる「住みよさ」の程度, 言い換えれば「生活の充実 度」と定義している. 加知ら ${ }^{18}$ は日常生活を想定し, QOLの構成要素を交通利便性(AC), 居住快適性(AM), 安全安心性(SS)に区分し, それら外環境の物理量に対し, 居住する個人の価值観を乗じてQOLの定量化を試みてい る.

一方，大規模災害発生時は，生存条件が劦かされる状 況であるため, 居住者が重きをおくニーズは平常時と大 きく様変わりする，被災直後には生命の維持，その後は 健康状態の維持，といったようにニーズは変化する. そ の後も, 被災地の環境変化に伴い, 被災者のニーズは 時々刻々と変化していく，したがって，災害時における 被災者のQOLは，各時点において顕在化するニーズと， そのニーズに対応する周辺環境の双方を考慮した上で評 価する必要がある.

\section{（2） 災害時QOLの決定構造}

Maslow ${ }^{19)}$ は，人間には生理的欲求，安全の欲求，社 会的欲求，尊厳欲求，自己実現欲求という，下位から上 位までの 5 段階からなる基本的な欲求構造が存在し，下 位の欲求が充たされるにつれて上位の欲求が高まるとい う仮説を示しており，人間の潜在的な欲求構造を可視化 したものとして知られている. 被災者のニーズ変化をそ のまま当てはめることは困難であるが，本研究では，周 辺環境亡被災者のニーズの変化に対応した災害時の QOL の構造を Maslow の仮説を参考に以下のように定義 する.

QOL は，下位から順にステージ 1）生命の保持，ステ

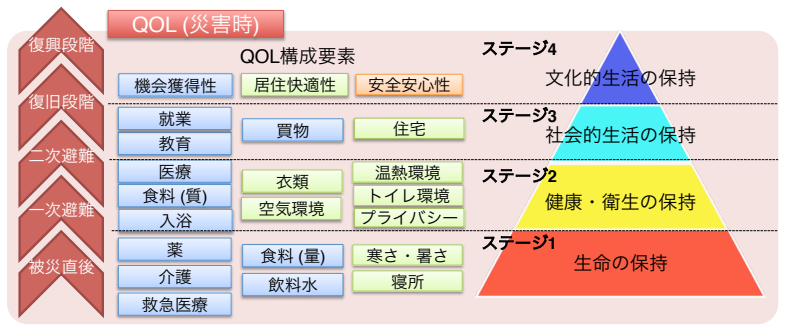

図-2 災害時のQOL構成要素の時系列変化と概念
ージ 2）健康・衛生の保持，ステージ 3）社会的生活の 保持，ステージ 4) 文化的生活の保持の 4 段階で構成さ れ，3）までは日本の平常時においては十分充足される. この際, 最上位のステージ 4) 文化的生活の保持は, そ れより下位の 1）～3）が充足されているニーズとして 顕在化するものと位置づける. 一方, 本研究で対象とす る災害時においては, 最下位の 1）から平常時と同じ 4）に回復するまでの QOL ステージ変化を扱う．以上の ような，被災後に時々刻々と変化する周辺環境，および 心理変化を考慮した災害時の QOL 構成要素の時系列変 化と概念について図-2に示寸。

\section{(3) 災害時 QOL 評価システム}

a) システムの概要

災害時のQOL評価システムの全体構成を図-3に示す。 このシステムは, 小地区単位（4分の1地域メッシュ単位, 一辺の長さ約 $250 \mathrm{~m})$ で，時系列で変化する被災者ニー ズに対して, 各時点のQOL構成要素とインフラの整備状 況との関係からニーズの充足状況を判定し, どのQOLス テージにあるかを特定する構造となっている.

\section{b) QOL構成各要素の充足 - 非充足判定方法}

QOL 構成各要素について，それが充足されるために 必要なインフラ等の要件が揃った場合を充足可能，それ 以外の場合を充足不可能と判定する. QOL 構成各要素 は，1)その場で充足可能な要素と，2)移動により充足さ れる要素の 2 種類に分けられる. 充足・非充足の判定方 法は以下のように整理される。

1) その場で充足可能な QOL 構成要素 :

QOL 構成要素を支えるインフラが全て機能している 場合に充足可能と判定.

2)移動によって充足される QOL 構成要素 :

道路や公共交通の接続性を考慮し, 居住地から到達可 能な範囲を特定し，その到達可能範囲内に目的施設があ れば充足可能と判定.

例えば，「入浴機会の確保」には「住宅」と「ライフ ライン(上下水道・ガス)」, もしくは「交通機関」と 「入浴施設」の組み合わせのうち，少なくともどちらか

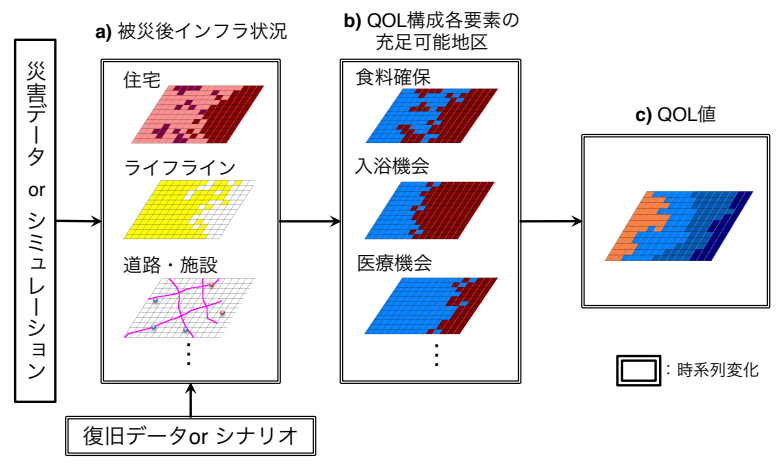

図-3災害時QOL評価システムの全体構成 
一方が正常に機能(復旧)している必要があることが示さ れている.この関係は式(1)のように定式化される.

$$
y=\left(x_{1} \wedge x_{2}\right) \vee\left(x_{3} \wedge x_{4}\right)
$$

ここで，yは入浴機会， $x_{1}$ は住宅， $x_{2}$ はライフライン（上 下水道・ガス）， $x_{3}$ は交通機関， $x_{4}$ は入浴施設に対応す る. 各変数は充足・機能している場合は 1 , 非充足・機 能停止の場合は0となる.

\section{c) QOLステージ判定とQOL值}

階層型の QOL 決定構造では, あるステージの構成要 素が充足されることでその QOL 水準が確保でき，それ によって上位のステージへの要求が発生することを仮定 している. 本研究では単純に, どの要素が久落してもそ のステージの QOL 水準は確保されないものと考え, あ るステージの QOL 構成各要素が全て充足可能となった 場合に，一つ上位ステージに移行するとして判定する.

各ステージで保証する QOL 水準は一定值をとるとし， 医療分野において時間損失法により求められた QOL 值 の参考值 ${ }^{20)}$ との比較から定量化する. その結果, 平常時 または文化的生活の保持の段階（ステージ 4）を全く健 康な状態と同等の 1 とし，生命の保持段階（ステージ 1）を 0.4 , 健康・衛生の保持の段階（ステージ 2）を 0.6, 社会的生活の保持の段階（ステージ 3）を 0.8 としてい る. 図-4 に QOL ステージの判定と各ステージの QOL 值と医療分野の QOL 参考值の対応関係を示す.

\section{d) 余命指標への換算}

QOL 值は最終的に,「生活の質により調整された生 存年数(Quality Adjusted Life Year：QALY)」を用いて評価 する，QALY は，健康状態に関連した生活の質(Health Related QOL : HRQOL)で調整される生存年数のことで, 死亡している状態を 0 , 健康な状態が 1 である，健康状 態は $0 \sim 1$ の值をとることになり，その状態の継続年数 を掛け合わせることでQALY の值が算出される.

本研究では災害影響評価を目的とするため, 式(2)で 示すように災害が発生しなかった場合の QALY から， 災害が発生した場合の QALY を差し引いた，損失余命 LLE(Loss of Life Expectancy)で評価する．図-5に QOL ステ ージの変化と損失余命の関係を示す.

$$
L L E_{p l}=\int_{0}^{\hat{t}}\left\{1-W_{p t}^{Q O L}(t)\right\} d t
$$

ここで， $L L E_{p l}$ は地区lの災害影響による健康な個人 $p$ の 損失余命， $\hat{t}$ は発災から復旧・復興までの期間， $W_{p t}^{Q O L}$ は健康な個人 $p$ が地区にで $t$ 日目に居住することで得られる QOL值である.

\section{（4）直接被害の算出方法}

直接被害については，内閣府中央防災会議より発表さ

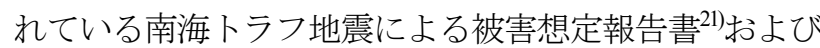

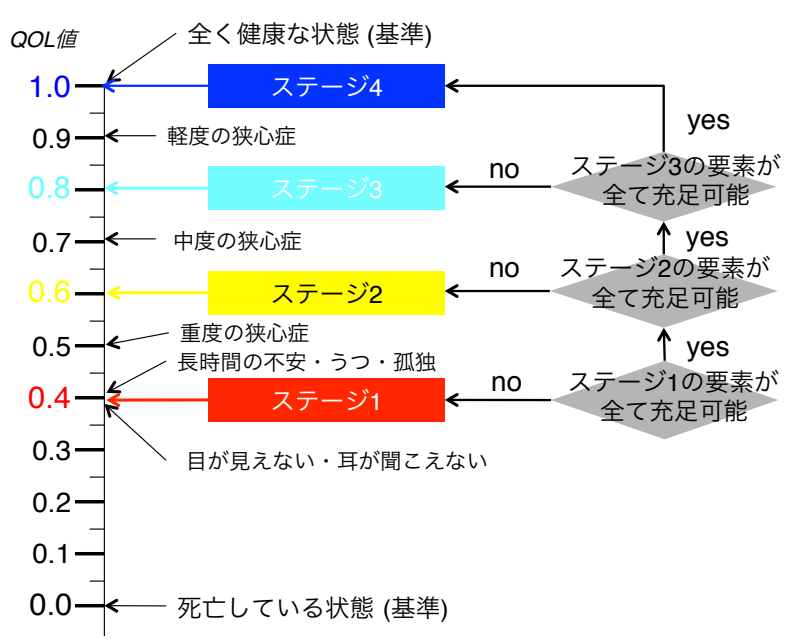

図-4 QOLステージと医療分野のQOL参考值との対応関係

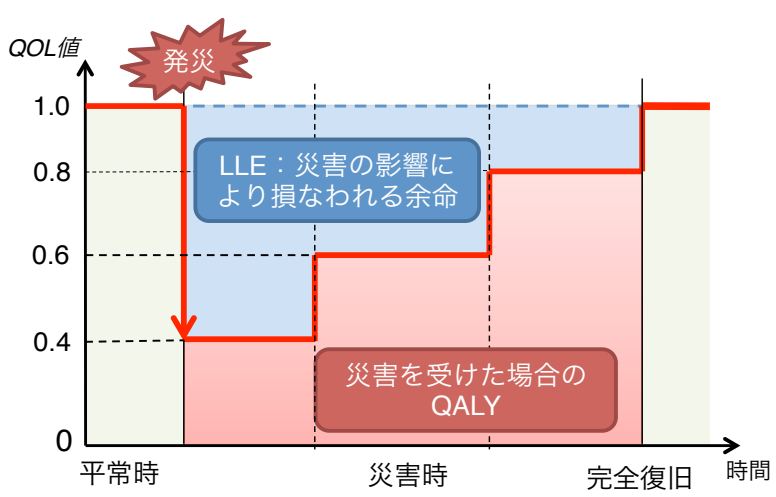

図-5 QOLステージの変化と損失余命の関係

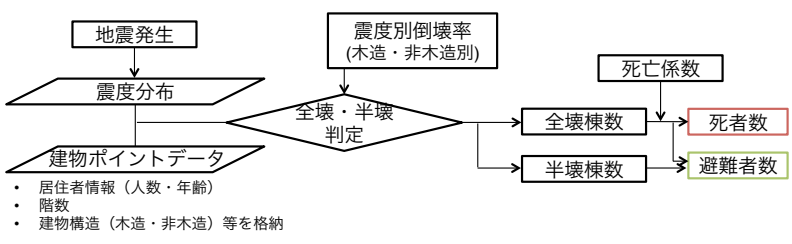

図-6＼cjkstart地震動による被害算出フロー

国土技術政策総合研究所の地震・津波被害想定マニュア ル22)に従い，直接被害による死傷者数を算出する．本研

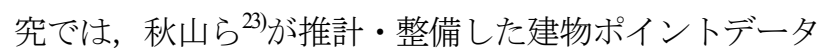
に格納されている，建物単位に割り振られた人口・世帯 情報を用い，小地区単位での被害判定を行う。ここでは， 地震および津波による人的被害についてそれぞれ述べる.

\section{a) 地震による人的被害}

地震動による直接被害の算出フローを図-6に示す。ま ず，想定地震の震度分布と震度別倒壊率により建物の全 半壊棟数および全壊棟数を算出する．死者は全壊時に発 生するとし, 建物内滞留率と死亡係数を乗じて求める.

一方，負傷者は全半壊時に発生するものとし，建物内滞 留率と負傷係数より求め, 津波被害時の避難判定の際に 使用寸る，建物倒壊，津波から生還し，建物が全壊，全 
半壊した棟数から避難者数を算出する.

\section{b) 津波による人的被害}

津波による直接被害の算出フローを図-7に示す。まず, 想定地震に伴う津波浸水深および津波到達時間から， 各々が居住建物から避難先（浸水域外, 津波避難タワー, 10階以上の建物）まで避難できるかを判定する．具体的 には居住建物と避難先を結ぶ最短距離について, 避難者 の年齢に応じた避難速度や避難開始時間を考慮して, 津 波到達時間までに避難所に到達可能かネットワーク計算 を行う．避難判定により避難が完了寸る場合は無傷，避 難が未完了である場合は津波に巻き込まれるものとし， 想定浸水域内の居住人口と浸水深，浸水深別死者率から 死者数を算出する．なお，地震動による建物倒壊に伴う 自力脱出困難者は津波からの避難ができないものとする. 浸水深別死者率については内閣府中央防災会議12) 設定 した浸水深別の死者率を用いる.

\section{4. 南海トラフ地震を対象としたケーススタディ}

\section{（1）地震及び津波の想定}

第3章で説明した大規模災害発生時のQOL評価手法を, 南海トラフ巨大地震によって甚大な被害が想定される静 岡県, 愛知県, 三重県に適用し, これらの地域のレジリ エンスを小地区単位（4分の1地域メッシュ単位）で評価 する. 地震の前提条件として, 震度分布は内閣府中央防 災会議の強震断層モデルにおける最大ケースを採用する. 津波は，津波断層モデルにおける「駿河湾〜紀伊半島沖 に大すべり域」を設定する.

\section{(2) 直接被害の予測}

図-8 に地震と津波による死者数について $250 \mathrm{~m}$ メッシ ユ単位での空間分布を示寸，このときの想定は，震災発 生時刻を深夜，建物内滞留率を $100 \%$ としている。 また， 津波避難の可否判定の際は, 東日本大震災の事例を参考 に, 避難速度を大人 : $2.65 \mathrm{~km} / \mathrm{h}, 65$ 歳以上の高齢者： $1.96 \mathrm{~km} / \mathrm{h}$ とし, 避難の開始時間は早期避難者率が高い場 合の発災 5 分後 : $70 \%$, 発災 15 分後 : $20 \%$, 津波到達後 避難：10\%と設定している. その結果, 死亡者数は静岡 県 115,310 人, 愛知県 13,470 人, 三重県 36,750 人（内閣

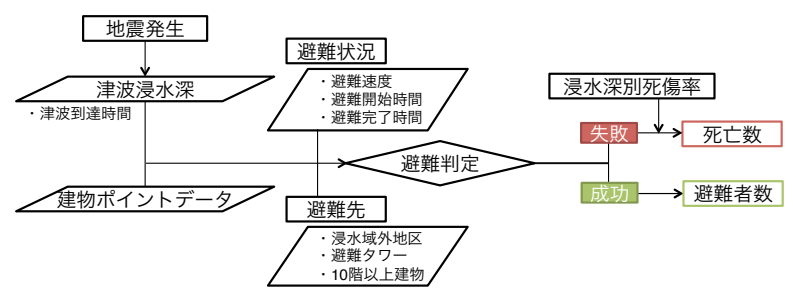

図-7＼cjkstart津波による被害算出フロー

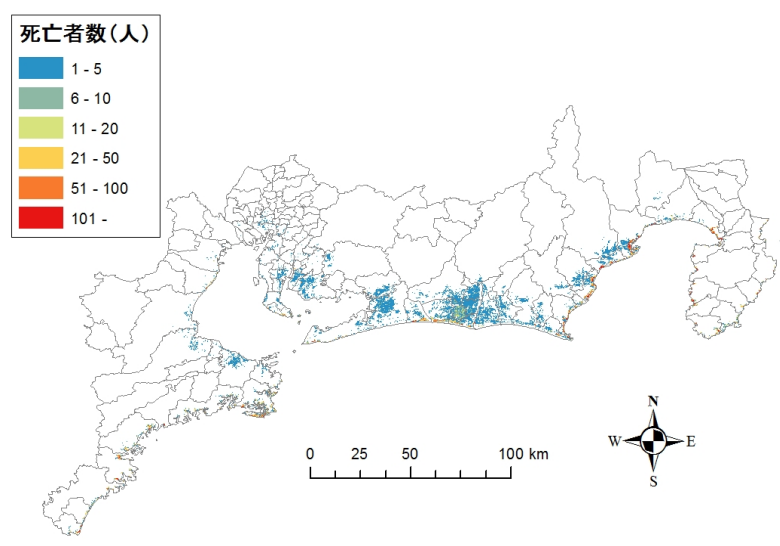

図-8 死亡者数の推計值

表-1 QOL構成要素の充足に寄与するインフラ

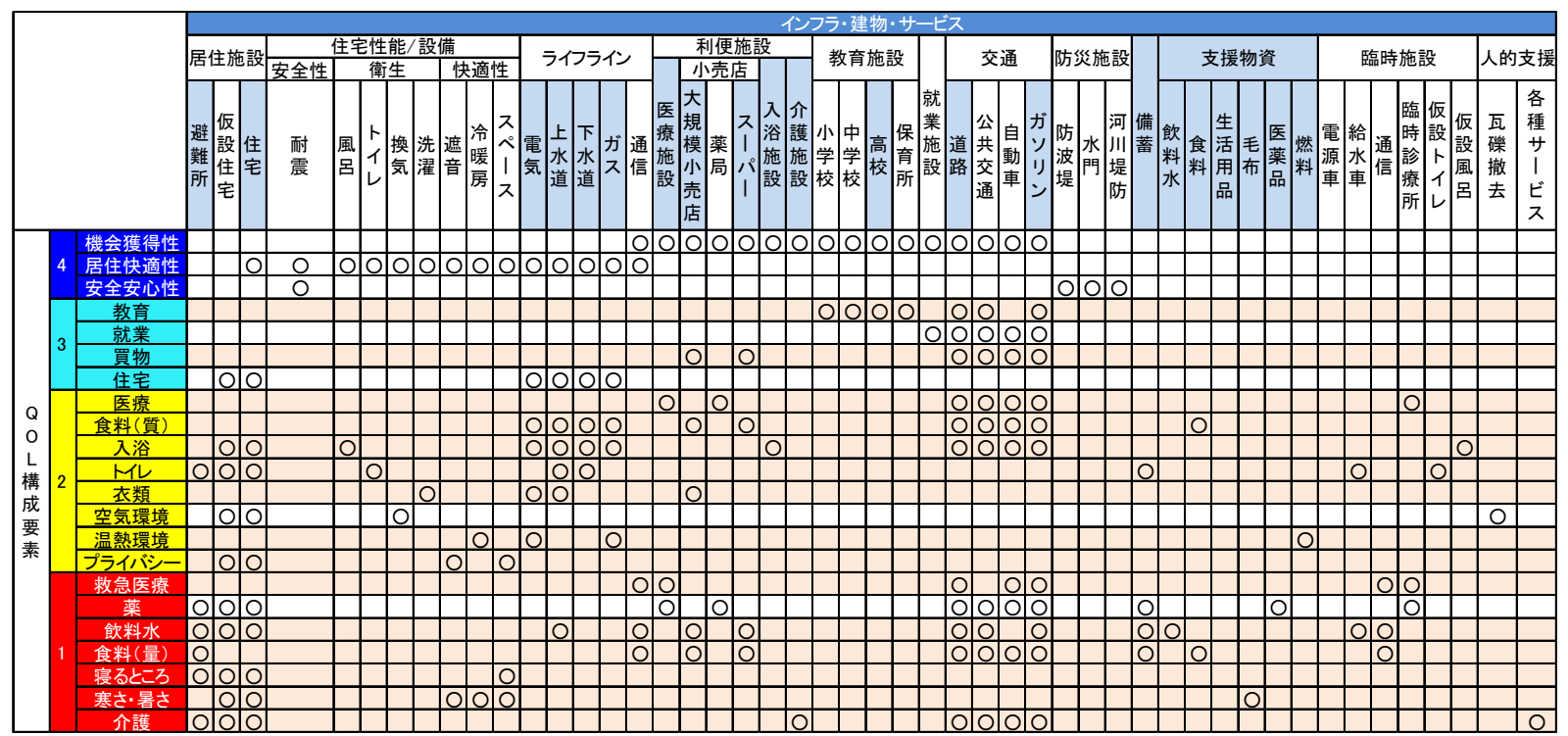


府試算 : 静岡県約 109,000 人, 愛知県約 23,000 人, 三重 県約 43,000 人) 21 となった.

\section{(3) 使用データ}

QOL 構成各要素とインフラ・建物・サービス要件を 表-1 にまとめる. 縦軸がステージごとの QOL 構成各要 素，横軸がインフラ等の項目を示しており，○印は QOL 構成各要素の充足に寄与するインフラ項目を示す インフラ項目で網掛けした部分が今回考慮したインフ ラ・建物・サービス要件である。また，QOL 構成各要 素の網掛け部分は今回考慮する要素である.ただし, 薬 の確保（ステージ 1），空気環境（ステージ 2）, 就業 機会（ステージ 3），住宅（ステージ 3）はデータ制約 により推計困難であったため, 推計から除外している. また，分析に利用したデータを表-2に示す.

対象とするライフラインは電力, 水道, ガスとし, 復 旧シナリオは，首都直下地震防災・減災特別プロジェク 卜総括成果報告書 ${ }^{24}$ によるライフライン復旧曲線に従い 作成した. なお，津波浸水域は機能停止と仮定する.ま た，対象とする交通インフラは道路とする. 中部地方幹 線道路協議会道路管理防災・震災対策検討分科会 ${ }^{25)}$ の基 本方針に従い，1)高速道路等の広域支援ルート，2)沿岸 部（被災地）アクセスルート，3)沿岸沿いルート，の優 先順序で啓開していくとする.

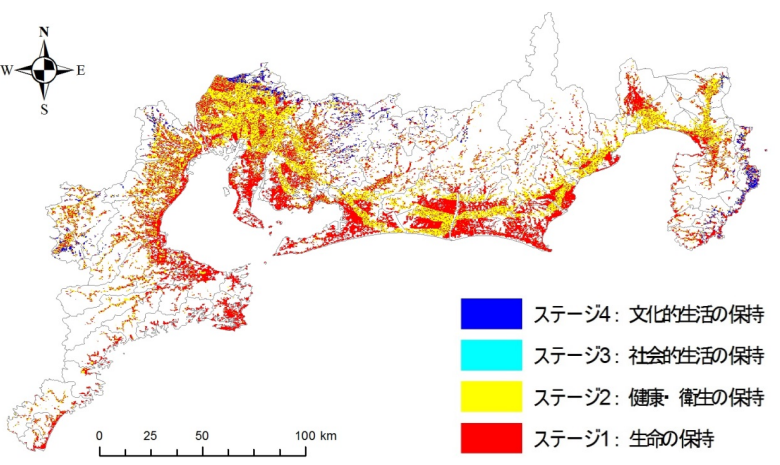

図-9 発災3日後のQOLステージ

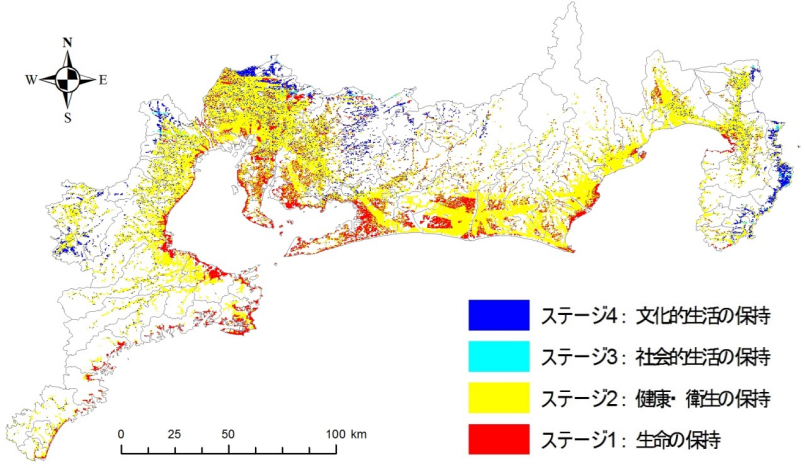

図-11 発災20日後のQOLステージ

\section{(4) 結果}

a) QOLステージの変化

南海トラフ地震発災日を基準日（0 日目）とし，被災 後の QOL 変化が顕著な約 2 か月後までの各地区におけ る QOL ステージの変化を図-9 から図-12 に示す.

全体の傾向として, 内陸部の QOL が先行して回復し ている一方で，沿岸部では津波被害によるインフラ損壊 が甚大であり，沿岸部居住者は避難生活を強いられるた め回復に時間を要している，発災から 3 日後には，道路 啓開の進展に伴い関東方面と関西方面を結ぶ東名高速道 路，新東名高速道路などの広域幹線網周辺地区の QOL

\begin{tabular}{|c|c|}
\hline デー夕項目 & 出典 \\
\hline 建物ポイントデータ & 秋山ら(2013) \\
\hline 避難所 & 国土数值情報 : 避難施設データ \\
\hline 備蓄 & $\begin{array}{l}\text { 愛知県危機管理局 : 愛知県の備蓄量一覽 } \\
\text { 三重県広域防災拠点施設基本構想 }\end{array}$ \\
\hline 医療施設 & 国土数值情報 : 医療施設データ \\
\hline 介護施設 & 国土数值情報 : 介護施設データ \\
\hline 入浴施設 & 国土数值情報 : 入浴施設データ \\
\hline 学校 & 国土数值情報 : 学校データ \\
\hline 福祉施設 & 国土数值情報 : 福祉施設データ \\
\hline スーパー & JPS : 日本スーパー年鑑ポイントデータ \\
\hline $\begin{array}{l}\text { ライフライン供給率 } \\
\text { (電力・水道・ガス) }\end{array}$ & $\begin{array}{l}\text { 東京大学地震研究所・防災科学技術研究 } \\
\text { 所・京都大学防災研究所 : 首都直下地震防 } \\
\text { 災・減災特別プロジェクト総括成果報告書 }\end{array}$ \\
\hline 道路ネットワーク & ESRI : ArcGIS データコレクション \\
\hline 緊急輸送道路 & 国土数值情報 : 緊急輸送道路データ \\
\hline 燃料供給所 & 国土数值情報 : 燃料給油所 \\
\hline
\end{tabular}

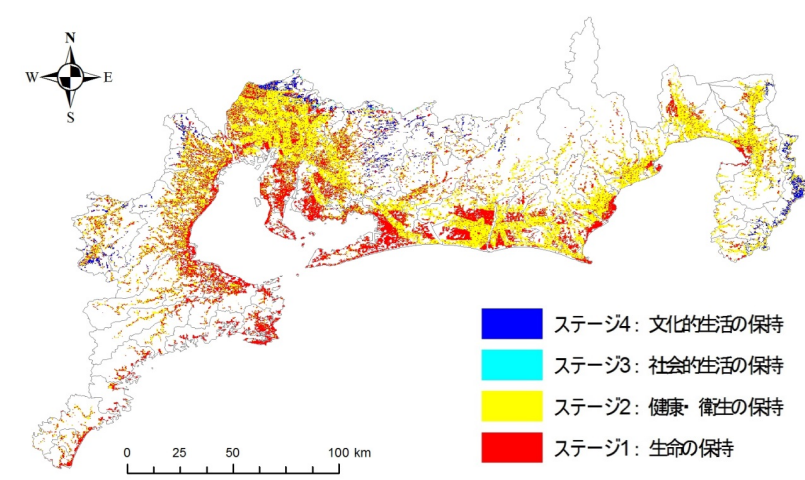

図-10 発災7日後のQOLステージ

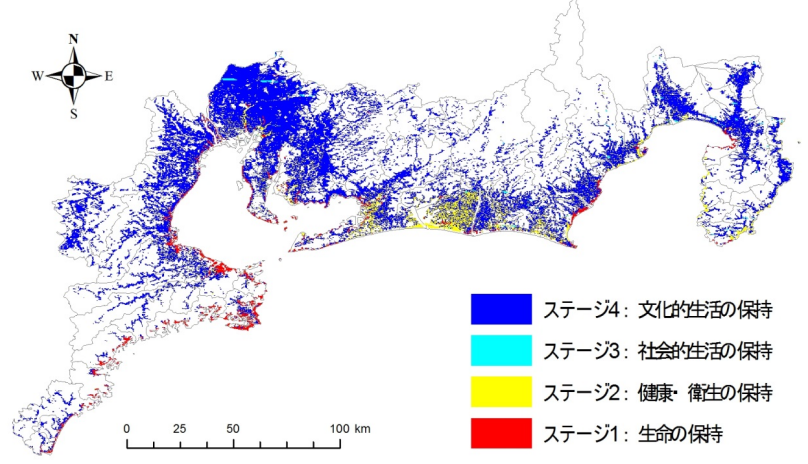

図-12 発災60日後のQOLステージ 
が回復し，徐々に沿岸部へと広がり，生命の保持の段階 （ステージ 1） から健康・衛生の保持の段階（ステージ 2）に移行している. 計測震度が 5 強程度の三重県北部 や愛知県北部，伊豆半島の東側ではすでに平常時（文化 的生活の保持の段階) の生活レベルまで回復する.

発災から 7 日が経過すると，道路啓開作業が沿岸部ま で到達し，津波浸水域の沿岸部でも生命の保持の段階か ら健康・衛生の保持の段階への移行が始まっている。 し かし, 特に三重県松阪市や志摩市以南のような, 他地域 からのアクセス性がそしく道路啓開作業が遅れる地域に は，未だ生命の保持の段階の地区が集中しており，この ような地域では，道路網の未整備区間を解消するなどリ ダンダンシーの確保が必要であるといえる.

発災から 20 日後には, 電力などのライフラインの供 給が安定化し，大規模崩壊した道路も道路啓開の段階か ら応急復旧の段階となり一般開放も進むため，地震動や 津波の直接被害が大きかった地域でも社会的生活の保持 の段階，あるいは文化的生活の保持の段階への移行がみ られる。

発災から60日後には，内陸部の大半の地域で文化的生 活の保持の段階までQOLは回復しているが，沿岸部でも 特に津波被害が大きい地域では依然として健康・衛生の 保持の段階にとどまっている.このように低ステージの 状態が長期化する地域では，被苂直後から一時移転を検 討することも必要であり, QOLステージが高い地域で受 け入れ準備しておくことも想定される.

\section{b) 損失余命算出結果}

図-13 は南海トラフ地震発災日を基準日とし, 基準日 から 30 日後，60日後までの約 2 か月間で被災地区に住 み続けた場合の 1 人当たりの損失余命を表している.こ の損失余命が大きいほど，災害の影響が大きい地区であ るといえる.

津波被害を受ける沿岸部では QOL の回復が遅れるた め大きい值を示しているが，同じ沿岸部でも道路復旧シ ナリオにおいて早期復旧した高速道路周辺地区は他の沿 岸部と比較して小さい值となっている. 一方で, 内陸部 では早急な QOL ステージの回復により小さい值になっ ている.

\section{c) 各QOLステージの人口割合の推移}

図-14 に各 QOL ステージの人口割合の推移を示す. ここでの人口とは，被災後も被災前に居住している地区 に住み続けているとしており，居住地区から他地区への 移転などによる人口増減は考慮していない.

被災から 20 日目までは時間の経過とともに道路啓開 が進み，他地区から避難地域への物資供給など支援が活 発となるため, 生命の保持の段階から健康・衛生の保持 の段階へ移行が目立つ. 20 日を過ぎてからは道路の応 急復旧が徐々に完了し始め水道やガスといったライフラ

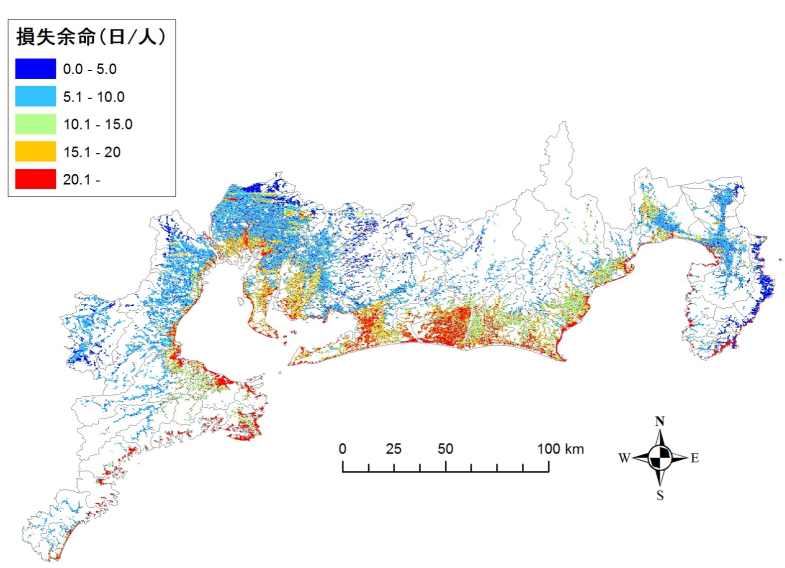

図-13 損失余命の推計結果

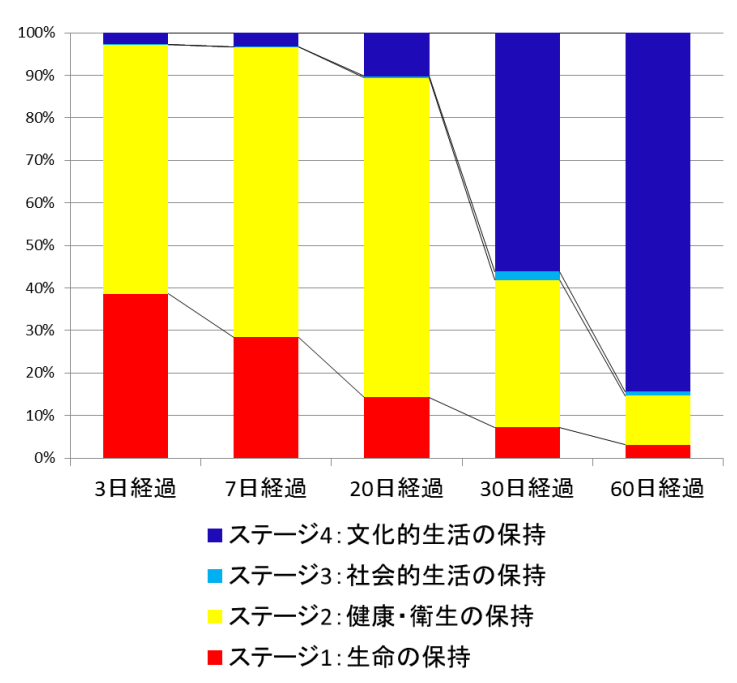

図-14 QOL各ステージの人口割合の推移

インの供給率も平常時に大幅に近づくため，健康・衛生 の保持の段階から社会的生活の保持の段階, 文化的生活 の保持の段階へと移行する.

しかし，発災から60日が経過しても未だ生命の保持 の段階にある地区が約 3\%あり，発災後の迅速な支援体 制の構築が求められる. あるいは, 発災前の事前対策と して，こうした地区への居住規制や避難体制の充実を図 る必要がある。

\section{5. おわりに}

大規模自然災害による被災者の QOL 低下量の時系列 変化を小地区単位で評価する手法を, 南海トラフ地震に おいて甚大な被害が予想される静岡県, 愛知県, 三重県 に適用し, 得られた QOL 低下量から地域のレジリエン ス性を評価した。 その結果以下の知見が得られた。

a) 南海トラフ地震の最大ケースでは，対象地域の内陸部 では QOL は回復したが，甚大な津波被害を被った沿岸 部において発生約 2 か月後も依然として生命の危機に瀕 
する地区があることが明らかになった.

b) 三重県の南部などの他地域からのアクセス性がそしい 地域では QOL の回復に多く時間を要する。このことか ら，ミッシングリンクの存在やネットワークのリダンダ ンシーの確保が QOL 回復に重要な役割を果たすことが 示された.

なお，QOL ステージの構成要素に大きく影響するラ イフラインの復旧率は，既往災害における被害データに 基づく関数となっている. 電力やガス事業者の他地域連 携や，上下水道の管種や敷設年など，地域特性を考慮し た，精緻な復旧率を設定することが今後の課題として挙 げられる.

謝辞：本研究は，文部科学省のグリーン・ネットワー ク・オブ・エクセレンス(GRENE)事業 環境情報分野「環 境情報技術を用いたレジリエントな国土のデザイン」， およひ環境省環境研究総合推進費「地域インベントリ解 析による環境成長拠点の計画と評価モデルの開発」(21404)の一環として実施したものである.ここに感謝の 意を表する.

\section{参考文献}

1) 復興庁：東日本大震災における震災関連死の死者数 (平成 28 年 3 月 31 日現在), http://www. reconstruction.go.jp/topics/main-cat2/sub-cat2-6/20160630_

kanrenshi.pdf (2016 年 7 月 9 日最終閲覧)

2) 内閣府: 平成 27 年版防災白書, 2015 .

3）上野山智也，荒井信幸：巨大災害による経済被害を どうみるかー阪神・淡路大震災・9/11 テロ・ハリケ ーンカトリーナを例として一, 内閣府経済社会総合 研究所, 2007.

4) 萩原泰治：神戸 CGE モデルによる阪神・淡路大震災 の影響に関する分析，国民経済雑誌，第 183 巻，第 1 号, 2001.

5) 国土交通省：新たなステージに対応した防災・減災 のあり方，http://www.mlit.go.jp/river/shinngikai_blog/ saidai_gaisui_naisui/01/pdf/r01.pdf（2016 年 2 月 26 日 最終閲覧)

6) 日本損害保険協会 : 洪水ハザードマップ等の現状・ 課題に関する調查研究, https://www.sonpo.or.jp/news/ file/00476.pdf（2016 年 2 月 26 日最終閲覧）

7) 近藤伸也, 照本清隆, 太田和良, 片家康裕, 高尾秀 樹, 河田恵昭：道路閉塞に着目した広域災害におけ る集落の孤立危険度マップの検討, 生産研究, 第 62 号, pp. 417-419, 2010.

8) 太田和良, 片家康裕, 坂口歩, 中瀬元浩, 澤田雅浩, 近藤伸也, 福留邦洋, 渡辺千明: 紀伊半島における 中山間地集落の孤立化と自立性に着目した防災力評 価手法の検討一東海・東南海・南海地震への戦略的 な防災対策の一環として一, 社団法人日本建築学会,
総合論文誌, No. 6, pp. 171-121, 2008.

9) 城仁士 : 阪神大震災における災害ストレスの実態調 查, 平成 7 年度ひょうご科学技術創造協会「阪神・ 淡路大震災に関連する緊急調査研究助成」研究実績 報告書, 28p., 1995.

10）松井克浩：被災生活におけるニーズと支援：中越地 震「生活アンケート」の試み, 日本行動計量学会第 33 回大会, 2005.

11) 紙野桂人：これからの安全都市づくり, 学芸出版, pp. 160, 1995.

12) 塚本直幸, 波床正敏: 都市インフラ機能低下への 人々の対応行動とインフラの整備要件, 土木計画学 シンポジウムテキスト, 32 巻, pp. 719-724, 1997.

13) 能島暢呂, 亀田弘行, 林春男: 地震時のライフライ ン機能障害に対する利用者の対応システムを考慮し た生活支障の評価法, 地域安全学会論文報告集, No. 3, pp. 195-202, 1993.

14) 塩野計司, 中林一樹, 高野公男: 震災時生活支障の 予測マップ, 地域安全学会論文報告集, pp. 387-394, 1995.

15）高野剛志, 森田紘圭, 戸川卓哉, 福本雅之, 三室碧 人，加藤博和，林良嗣：東日本大震災における被災 者生活環境の時間的变化の評価, 土木学会論文集 D3 (土木計画学), Vol. 69, No. 5, pp.I_125-I_135, 2013.

16) 杉本賢二, 橘竜瞳, 森田紘圭, 加藤博和, 林良嗣 : 大規模自然災害に伴う生命・健康・生活へのダメー ジの余命指標を用いた評価, 土木学会論文集 D3 (土 木計画学), Vol. 71, No. 5, pp. 121-128, 2015.

17) Myers, D. : Building knowledge about quality of life for urban planning, APA Journal, pp. 79-106, 1998.

18) 加知範康, 加藤博和, 林良嗣, 森杉雅史 : 余命指標 を用いた生活環境質(QOL)評価と市街地拡大抑制策検 討への適用, 土木学会論文集 D, Vol. 62, No. 4, pp. 558-573, 2006.

19) Maslow, A. H. : A theory of human motivation, Psychological Review, Vol. 50, No. 4, pp. 370-396, 1943.

20) 小笠原克彦：費用便益分析と QOL, 日放技学誌, Vol 63, No. 7, pp. 791-795, 2007.

21）内閣府中央防災会議: 南海卜ラフの巨大地震 建物被 害・人的被害の被害想定項目及び手法の概要, 南海 トラフ巨大地震対策検討ワーキンググループ，2012.

22）国土交通省 国土技術政策総合研究所：公共土木施設 の地震・津波被害想定マニュアル，2008.

23) 秋山祐樹, 小川芳樹, 仙石裕明, 柴崎亮介, 加藤孝 明：大規模地震時における国土スケールの災害リス ク・地域災害対応力評価のためのミクロな空間デー 夕の基盤整備, 第 47 回土木計画学研究 ・講演集 (CD-ROM, 392)，2013.

24) 東京大学地震研究所, 防災科学技術研究所, 京都大 学防災研究所：首都直下地震防災・減災特別プロジ エクト総括成果報告書, 2012 .

25）中部地方幹線道路協議会 : 中部版くしの歯作戦, 道 路管理防災・震災対策検討分科会, 2014.

(2016. 2. 26 受付) 
EVALUATION OF REGIONAL RESILIENCE BASED ON THE CHANGE IN THE

SURVIVAL AND LIFE ENVIRONMENT AFTER LARGE-SCALE DISASTERS

\section{Satoru INOHARA, Keita WATANABE, Kenji SUGIMOTO, Hirokazu KATO and Yoshitsugu HAYASHI}

It is important to develop the information of the resilience of the region for large-scale natural disasters in order to take measure of disaster prevention and disaster mitigation. This study tries to evaluation of regional resilience based on decrease in Quality of Life (QOL) after large -scale disasters by simulating direct damage and setting recovery scenarios. Result of applying Nankai Trough earth quake, QOL in the inland was recovered, but in the coastal area that suffered Tsunami damage, QOL of recovery was slow. By recovery scenarios of road assumed on the basis of the policy of "Kushi no ha operations" support advances from the areas along major highway surrounding area, showed that play an important role in QOL recovery. 